\title{
PENGELOMPOKAN MASYARAKAT NEGERI TUHAHA PULAU SAPARUA, MALUKU TENGAH
}

Tinjauan Etnoarkeologis

\author{
The Classification of Tuhaha Village Community \\ in Saparua Island, Central Mollucas \\ An Ethnoarchaeological Perspective
}

\author{
Lucas Wattimena \\ Balai Arkeologi Ambon \\ Jl. Namalatu - Latuhalat, Ambon 97118 \\ Email : lucas.wattimena@yahoo.com
}

Naskah diterima: 18-01-2013; direvisi: 14-08-2013; disetujui: 06-09-2013

\begin{abstract}
The Meaning of Tuhah a community's grouping based on archaeological remains can not be separated from one another, due to the partial temporal nature. This study used a literature study, in order to examine the issue of research, how society grouping Tuhaha State, based on archaeological remains. Archaeological remains is meant here is a dolmen, menhirs and the old village / ancient settlements. The objective of this study is to know and understand the patterns of grouping Tuhaha State community based archaeological remains. The results showed that grouping State community / village Tuhaha archaeological remains contextually based culture has symbolic interaction, integration and socio-cultural systems on the basis of grouping patterns in the structure of the dolmen, menhirs(micro scale) and Old village Huhule (macro scale). Huhule as anintegral unity of the social system, in which there are parts of the system dolmen, menhirs, as well as the concepts of cultural mapping (monodualisme). Integration between the dolmen of five, symbolizing Patalima community groups, and soa of nine (patasiwa).
\end{abstract}

Keywords: Classification Society, Dolmen, Menhir, Soa.

\begin{abstract}
Abstrak
Pemaknaan pengelompokan masyarakat Tuhaha berdasarkan tinggalan arkeologis tidak dapat dipisahkan satu dengan yang lain, disebabkan oleh sifat temporal parsial. Penelitian ini menggunakan kajian kepustakaan, guna menelaah permasalahan penelitian, yaitu bagaimana pengelompokan masyarakat Negeri Tuhaha, berdasarkan tinggalan arkeologi. tinggalan arkeologis yang dimaksudkan di sini adalah dolmen, menhir serta kampung lama/permukiman kuno. Tujuan daripada penelitian ini adalah untuk mengetahui dan memahami pola pengelompokan masyarakat Negeri Tuhaha berdasarkan tinggalan arkeologis. Hasil penelitian menunjukan bahwa Pengelompokan masyarakat Negeri/Desa Tuhaha berdasarkan tinggalan arkeologis secara kontekstual budaya memiliki hubungan interaksi simbolik, integrasi dan sistem sosial budaya atas dasar pola pengelompokan pada struktur dolmen, menhir (skala Mikro) dan kampung Lama Huhule (skala Makro). Huhule sebagai kesatuan sistem sosial integral, yang di dalamnya terdapat bagian sistem dolmen, menhir, serta konsep-konsep pemetaan budaya (monodualisme). Integrasi antara dolmen berjumlah lima, melambangkan kelompok masyarakat patalima, dan soa berjumlah sembilan (patasiwa).
\end{abstract}

Kata Kunci : Pengelompokan Masyarakat, Dolmen, Menhir, Soa. 


\section{PENDAHULUAN}

Pulau Saparua secara administratif termasuk Kabupaten Maluku Tengah dengan Ibukota Kecamatan Pulau Saparua membawahi 16 negeri/desa dan 1 dusun/ kampung. Di antara negeri-negeri/desa yang ada di Saparua, Tuhaha merupakan salah satu negeri/desa yang memiliki tinggalan arkeologis yang pola sebarannya cukup banyak dan beragam. Di antaranya yaitu dolmen, menhir dan permukiman lama/ kampung lama.

Negeri Tuhaha dipimpin oleh seorang Raja dan dibantu oleh staf Pemerinta Negeri, yaitu sekretaris, kepala-kepala soa, saniri negeri, dan Kaur-Kaur (Kepala Urusan). Batas-batas wilayah petuanan Negeri/Desa meliputi; Negeri Itawaka di sebelah timur, Ihamahu dan Ullath. Neger administratif Mahu di sebelah utara. Sebelah selatan dengan petuanan Negeri Sirisori dan bagian barat dengan Teluk Tuhaha dan petuanan Negeri Saparua. Untuk mencapai Negeri Tuhaha dapat ditempuh dengan menggunakan transportasi laut, sepert speedboat dengan lama perjalanan kurang lebih 2 jam. Namun apabila menggunakan kapal cepat membutuhkan waktu hanya 1 jam perjalanan tiba di pelabuhan Negeri Haria Selanjutnya untuk mencapai Negeri Tuhaha harus menempuh perjalanan darat dengan kendaraan roda empat atau dua sekiar 30 menit.

Penelitian yang dilakukan oleh tim Balai Arkeologi Ambon pada tahun 2008 dan 2011 telah menemukan 5 (lima) buah dolmen dan 2 (dua) menhir, serta sebuah kompleks permukiman lama. Marlyn Sahulteru seorang peneliti prasejarah (megalitik) Balai Arkeolog Ambon pernah melakukan penelitian di Pulau Saparua, mengatakan bahwa tinggalan arkeologis disana memiliki beberapa aspek struktur territorial yaitu : 1) pola sebaran dolmen. 2) pola penempatan dolmen, dan 3) faktor yang mempengaruhi pola penempatan dolmen (Salhuteru, 2008)

Studi etnoarkeologi adalah suatu cabang studi arkeologi yang memanfaatkan data etnografi sebagai analogi untuk memecahkan masalah-masalah arkeologi. kajian ini didasarkan penalaran induktif sehingga kedudukannya hanya bersifat memberikan contoh (sampel) untuk interprestasi, menyajikan kemungkinan awa (prior-probability), atau menilai kelayakan hipotesis. Hasil kajian etnoarkeologi tidak memberikan pembuktian benar atau tidaknya hipotesanya, karena bukan merupakan uji penyimpulan induktif. Kajian itu hanya perluasan dari proses induktif itu sendiri atau abduksi. Jadi kajian etnoarkeologi bukannya untuk menjelaskan gejala yang teramati saa ini (data etnografi), tetapi sekedar memberika gambaran kemungkinan adanya persamaaan antara gejala budaya masa lampau dengan budaya masa kini, atau sebagai argumentas penghubung (bridging arguments) dalam rangka uji hipotesis, model, dan teori ( Tim Penyusun, 2008 : 188).

Selanjutnya informasi mengenai kerangka konseptual tinjauan etnoarkeologis belum terlalu lengkap dan maksimal. Tulisan ini mencoba memberikan gambaran pandangan kontekstual dari segi etnoarkeologi terhadap pengelompokan masyarakat Negeri Tuhaha di Pulau Saparua Kabupaten Maluku Tengah berdasarkan tinggalan arkeologis. Tinggalan arkeologis yang dimaksudkan oleh penulis disini adalah dolmen, menhir dan Negeri Lama/Permukiman Lama. Penulisan ini lebih difokuskan kepada hubungan sistem nilai tinggalan arkeologis terhadap pengelompokan masyarakat Tuhaha, dengan menggunakan pendekatan etnoarkeologi. Kajian etnoarkeologi (Tanudirjo, 2009 :34) dibagi menjadi tiga kelompok; Pertama, disebutkan kajian etnografi yang secara informal memberikan informasi kepada ahl arkeologi. Disebut etnoarkeologi informal kalau pengamatan etnografi dilakukan hanya sekilas saja tetapi dimaksudkan untuk kepentingan arkeologi. Kedua, etnoarkeologi yang mengkaji secara khusus salah satu aspek tertentu dari budaya yang masih hidup, misalnya mata pencaharian, teknologi, atau religi. Ketiga, etnoarkeologi yang menelaah secara mendalam seluruh budaya masyarakat yau konteks penciptaan budaya bendawi. Ahli lainnya Schiffer (Tanudirjo, $2009: 3$ ) menyatakan "etnoarkeologi adalah kajian tentang budaya bendawi dalam sistem budaya yang masih ada untuk mendapatkan informasi, khusus maupun umum, yang dapat berguna bagi dapat berguna bagi penelitian arkeologi". Etnoarkeologi menelisik hubungan antara tindakan manusia dan budaya bendawi di masa kini untuk menyediakan prinsip-prinsip yang dibutuhkan dalam kajian tentang masa lampau.

\section{METODE}

Metode penelitian menggunakan studi kepustakaan. Arkeologi sebagai sebuah disiplin ilmu tidak terlepas dari pemahaman tentang kebudayaan masa lalu yang didasarkan pada tiga tujuan yaitu rekonstruksi sejarah budaya, rekonstruksi cara-cara hidup, dan penggambaran proses budaya (Binford, 1972 : 104). Hal tersebut bermula dari sebuah artefak yang ditemukan, yang nantinya dalam khasanah arkeologi akan menjadi sebuah budaya materi dengan segala elemen pendukungnya seperti; manusia, alam lingkungan dan ekosistem. Artefak pada dasarnya merupakan manifestasi dari suatu konsep atau budaya materi. Artefak itu sendiri juga merupakan hasil transformasi dari tingkah laku individu ataupun kelompok pendukung budaya yang bersangkutan, dan tidak secara langsung merefleksikan perilaku masyarakat (Hodder, 1986).

\section{HASIL DAN PEMBAHASAN}

Tinggalan Arkeologis di Tuhaha; Kebudayaan Tangiable Sebagai Struktur Dasar

Masyarakat Negeri/Desa Tuhaha memahami dan mengetahui akan pentingnya tinggalan arkeologis; dolmen $1^{l}$, menhir, permukiman lama/negeri lama. Bagi mereka tiap tinggalan arkeologis dari masing-masing kategorisasi merepresentasikan pondasi ${ }_{1}^{1}$ dolmen batu meja,
huhule permir batu banting kepala, dan dinamika kebudayaan nenemoyang mereka dari dulu hingga sekarang. Secara eksplisit dikatakan bahwa penduduk Negeri/Des Tuhaha tumbuh dan berkembang awal mulanya dari huhule ${ }^{2}$. Geria (2008), menyebut bahwa hubungan manusia dengan lingkungan tidak terlepas dari sistem budaya, teknologi, sistem sosial dan idealogi (Geria, 2008 : 89). Seperti diketahui selain dipengaruhi oleh lingkungan, manusia dengan sistem budayanya juga mempengaruhi dan mengubah lingkungan baik fisik (abiotik), hayati (biotik) maupun lingkungan sosial.

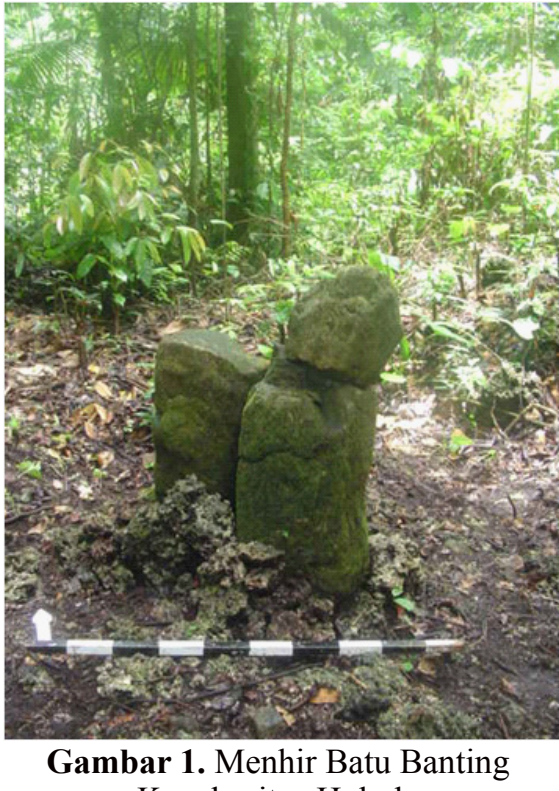
Kepala situs Huhule

Sumber: Dokumen Balai Arkeologi Ambon, 2008)

Dengan demikian dapat dilihat bahwa masyarakat Negeri/Desa Tuhaha mengalam perubahan-perubahan seiring dengan perkembangan kebudayaan, dilihat mulai dari masa waktu ketika mereka masih hidup berkelompok di kampung lama huhule. Mereka hidup dalam kelompok $s o a^{3}$, antar lain soa huhule, soa amapatal, soa talehu, soa amapuano, soa matalete, soa apalili, soa tahapau, soa amutai, soa sopake. Kesembilan soa ini secara eksplisit telah melambangkan siwa (patasiwa) kelompok sembilan. Di bukit huhule ditemui juga dolmen berjumlah 5 buah, yang secara ekplisit juga melambangkan kelompok lima (patalima), antara lain dolmen 2 Permukiman lama/negeri lama. 3 Kumpulan beberapa matarumah/fam/marga 
sahusilawane, dolmen kapitan aipassa dolmen siwalima, dolmen supusepa, dolmen pattipeluhu.

Konsep monodualitis orang-orang Uli Siwa dan Uli Lima dari kepercayaa asli dan adat yang dianut, bahwa dunia dibentuk oleh dua unsur yang berbeda. Pandangan ini merupakan pengakuan adanya perbedaan, walaupun konsekuensinya dapat menimbulkan konflik atau persaingan antara satu dengan yang lain. Masing-masing berhadapan sebagai dua yang berbeda tetapi tidak untuk saling memusnahkan. Jadi menjaga dua yang berbeda sama dengan menjaga adat dan pranata sosialnya untuk tetap hidup dan berkembang (Huliselan, 2005 : 230).

Berdasarkan pendapat di atas, maka perbedaan dalam pengelompokan masyaraka Negeri/Desa Tuhaha bukan sesuatu hal atau indikator pemicu perbedaan, tetapi keseimbangan dua dalam berkembang lebih baik. Susunan struktur pengelompokan soa penduduk Negeri/Desa Tuhaha berdasarkan tinggalan arkeologis jelas terdapat pemahaman dan pandangan monodualisme, yaitu Sembilan Soa Dan Lima Dolmen.

Pada masa transisi, ketika masuknya bangsa penjajah Belanda di Maluku umumnya dan Saparua pada khususnya, Negeri/ Desa Tuhaha sangat merasakan dampak kolonialisasi, baik segi integritas, struktur masyarakat, pola kemasyarakatan dan lain sebagainya. Misi bangsa penjajah Belanda waktu itu adalah pengusaan daerah jajahan, sehingga tindakan politik apapun akan digunakan untuk menguasai daerah jajahannya, tidak serta merta dengan menggunakan tindakan kekerasan bahkan hingga kematian.

Menurut cerita tua-tua adat ${ }^{4}$ Negeri/ Desa Tuhaha, pada waktu itu dibawah Jendral A Van Qudshoorn diperintahkan Van Qudshoorn diperintahkan
untuk seluruh penduduk yang ada 4 Wawancara dengan Bapak Saniri Negeri/Desa Tuhaha,
Raja Negeri/Desa Tuhaha Maret 2012. di gunung 5 untuk segera turun ke pante membuat permukiman baru, tinggal dan menetap. Usulan perintah penjajah untuk menurunkan penduduk dari negeri lama diterima oleh Upu Latu Ulisiwa Kapitan Aipassa, dan langsung ditanggapi dengan memanggil dan mengumpulkan para masyarakatyang ada di negeri lama pada waktu itu. Kemudian dilakukan sidang saniri negeri digelar dengan agenda menerima atau tidak menerima perintah penjajah Belanda yang mer seluruh pemukiman yang ada di gunung harus segera turun ke pantai. Tetapi Kapitang ${ }^{7}$ Aipassa menolak dan mengadakan perlawanan bersama saudara dari Iha atau UlupahaAmalatu. Pertempuran pun terjadi dan tidak dapat terhindarkan dengan korban jiwa dari kedua belah pihak. Kekuatan dari Belanda waktu itu sangat lemah, bahkan hampir kalah total, tetapi mereka menggunakan strategi memakai orang pribumi untukmelawan orang thang pribumi sendin, yaitu bantuan dari Ullath, Tuhaha dan Paperu untuk melawan kekuatan besar Ulupaha Amalatu.

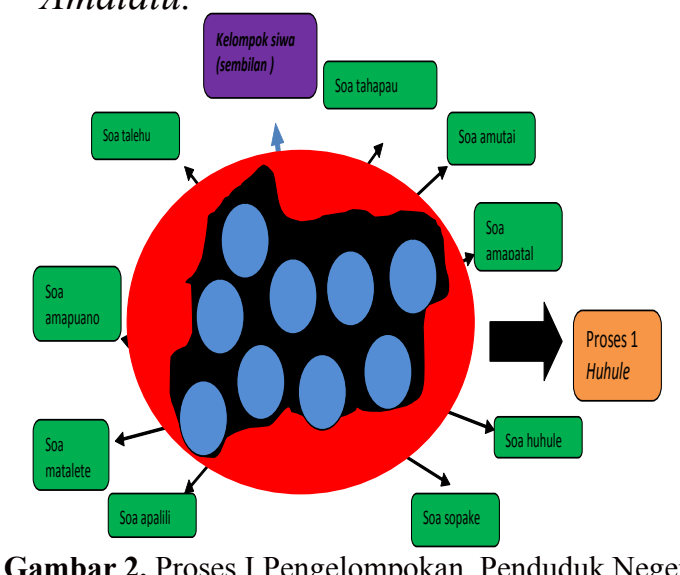

Gambar 2. Proses I Pengelompokan Penduduk Nege (Sumber : Hasil Penelitian)

5 Gunung yang dimaksudkan adalah huhule.

7 Ahli perang atau orang yang pandai ilmu berperang

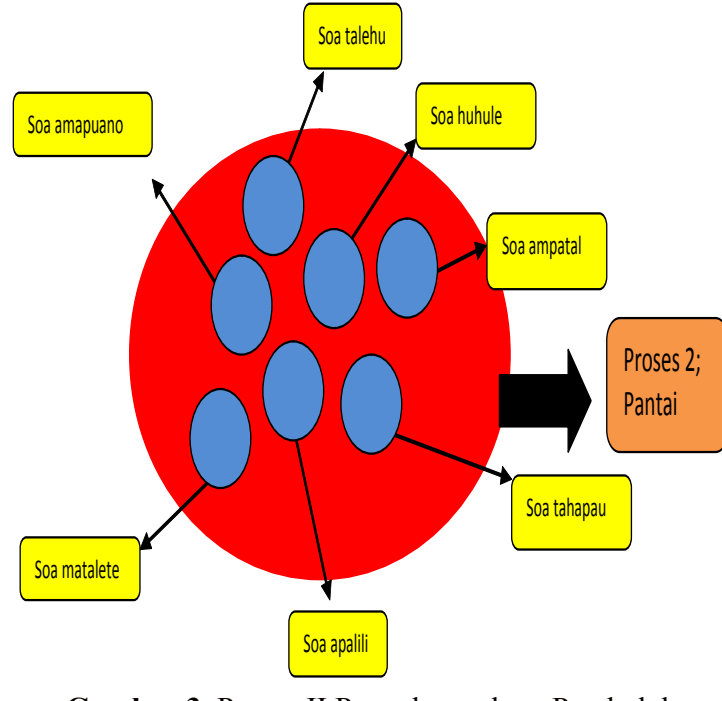

Gambar 3. Proses II Pengelompokan Penduduk Negeri Tuhaha Berdasarkan Strukt
Tinggalan Arkeologis. (Sumber : Hasil Penelitian)

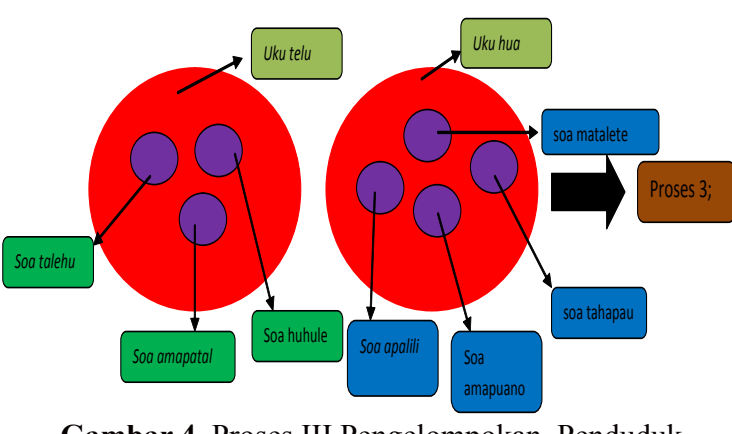

Gambar 4. Proses III Pengelompokan Penduduk egeri Tuhaha Berdasarkan Strukt Tinggalan Arkeologis.

Tingkat mikro mempelajari hubungan antar ruang dalam satu unit bangunan (micro spatial pattern). Tingkat semi mikro mempelajari hubungan antar unit ruang dalam satu komunitas (situs), sedangkan tingkat makro mempelajari hubungan antar situs yang meliputi beberapa komunitas (macro spatial pattern) (Clarke, 1977). Setelah mereka turun ke pantai hanya tersisa 7 kelompok soa yaitu soa pololouw, soa keluhu, soa samasulu, soa matita, soa lounusa, soa louhena, soa silou. Integrasi sosial ketika sudah berada di pantai, tidak dapat dipungkiri telah terjadi perubahan-perubahan, dimana struktur soa amutai dan soa sopake telah hilang sebelum bergabung di pantai. Alhasil ada identitas pola pengelompokan -pengelompokan baru, yaitu soa lounusa, louhena,keluhu, samasulu.
Perubahan tersebut mungkin saja terjadi atas nama, tetapi struktur dasar dalam soa tidak berubah. Berikut dapat dilihat pada gambar 2 proses pengelompokan penduduk Negeri Tuhaha berdasarkan struktur tinggalan arkeologis.

Pada proses yang ketiga 7 (tujuh) kelompok soa yang ada dikelompokkan dalam $u k u^{8}$ yaitu $u k u$ Telu dan Uku Hua. Kedua $u k u$ tersebut memiliki posisi sesuai peran dan fungsinya, yaitu sebelah utara $U k u$ Haa, sebagai penjaga pintu belakang waktu di huhule, sedangkanuku Telu sebagai penjaga pintu muka, yakni pada bagian selatan.

Hubungan dolmen, menhir, pemukiman lama/negeri lama dengan masyarakat

Dolmen ${ }^{9}$, menhir ${ }^{10}$ merupakan salah satu bagian dalam tinggalan arkeologi megalitik. Peninggalan megalitik secara holistik mensubstansikan ciri tertentu kebudayaan pada masa itu. Ciri kebudayaan ditunjukan dengan berbagai bentuk, susunan, tingkatan temuan megalitik dengan merumuskan nilai-nilai sosial, budaya, politik, ekonomi, dan lain sebagainya, atas dasar gagasan, ide manusia masyarakat pada masa itu. Goodenough (dalam Dilistone, 2002 : 19) mengatakan simbol adalah barang atau pola yang, apapun sebabnya, bekerja pada manusia, dan berpengaruh pada manusia, melampui pengakuan semata-mata tentang apa yang disajikan secara harafiah dalam bentuk yang diberikan itu. Dengan demikian substansi megalitik disini adalah interprestas kontekstual manusia masyarakat pada masa itu, dengan dalil bahwa semacam pemahaman 8 Uku atau Huku merupakan perkembangan dari rumatau/ lumatauyang terjadi pertambahan jiwa dan anggota keluarga sehingga rumah induk tidak dapat menampung, maka anggota kela pat tinggal baru yang berdekatan dengan rumah indu Dolmen yaitu mej bith susman batu yang

sebuah batu yang ditopang oleh beberapang terdiri dari sehingga menyerupai meja (Tim Penyusun, 2008 : 84). 10 Menhir adalah sebuah monolit, baik yang dikerjakan maupun tidak, dengan dimensi panjang, lebar, tebal. Menhir didirikan tegak di permukaan tanah (Tim Penyusun, 2008: 85) 
interaksi antara manusia dan manusia, manusia dan alam, bahkan alam dengan alam. Dalam perkembangan manusia pada setiap lapisan budaya tidak dapat dipungkiri akan nilai-nilai yang terkandung pada tinggalan arkeologis, khususnya di Negeri/Desa Tuhaha.

Tinggalan arkeologi yang ditemukan tim penelitian BalaiArkeologi Ambon di Negeri/Desa Tuhaha, antara lain :

- Dolmen Sahusilawane (Talehu)

- Dolmen Supusepa

- Dolmen Pattipeluhu

- Dolmen Siwalima

Dolmen Kapitang Aipassa (Salhuteru, 2008: 86-90)

Berikut dapat dilihat model diagram pola pengelompokan masyarakat Negeri/ Desa Tuhaha berdasarkan tinggalan arkeologis, model diagram ini adalah pola pengelompokan waktu mereka masih di huhule (permukiman lama). Setiap kelompok direpresentasikan melalui dolmen, sehingga dengan jelas dapat dilihat bahwa kelompok-kelompok terintegrasidi dalam huhule. Selain daripada itu pengelompokan dolmen juga atas dasar lima. Masyarakat Maluku, khususnya MalukuTengah memiliki pembagian kelompok masyarakat Patasiwa dan Patalima. Pembagian dolmen beserta kelompoknya dapat didasarkan pada pembagian patalima. Untuk lebih jauh dan memaknai pengelompokan patasiwa dan patalima atas tinggalan arkeologis masih harus dilakukan penelitian dan pengkajian mendalam lagi.

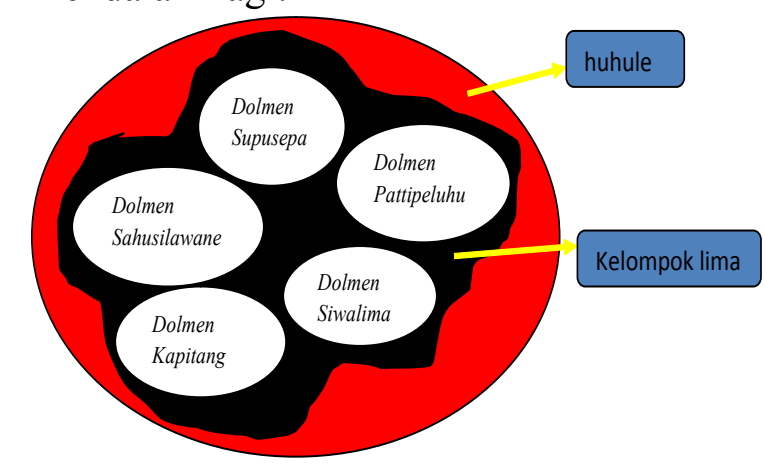

Gambar 5. Diagram Pengelompokan Masyarakat
Negeri Tuhaha Berdasarkan Tinggalan Arkeologi (Sumber : Hasil Penelitian)
Melville dan Malinowski mengemukakan bahwa cultur determinism berarti segala sesuatu yang terdapat $d$ dalam masyarakat ditentukan adanya oleh kebudayaan yang dimiliki oleh masyaraka itu (Soerjono, 1990 : 187). Oleh karena itu model pengelompokan masyarakat Negeri Desa Tuhaha waktu masih di Huhule bukan semata-mata hanya pengaturan biasa, tetap kebudayaan (gagasan, ide) yang dimilik merekalah yang mendorong seperti demikian. Kemudian Herkovits memandang kebudayaan sebagai sesuatu yang superorganic, karena kebudayaan yang turun temurun dari generas ke generasi tetap hidup terus (Soerjono, 1990 : 187). Kehidupan sosial pada dasarnya adalah interaksi manusia dengan menggunakan simbol-simbol. Manusia menggunakan simbol-simbol yang merepresentasikan apa yang mereka maksudkan untuk berkomunikas dengan sesamanya, dan juga berpengaruh yang ditimbulkan penafsiran atas simbolsimbol ini terhadap prilaku pihak-pihak yang terlibat dalam interaksi sosial (Mulyana, 2010 71)

Seperti yang telah dijelaskan sebelumnya bahwa Negeri/Desa Tuhah memiliki tujuh soa yang terdiridari beberapa matarumah/fam/marga berikut dapat dilihat pada tabel matarumah Negeri Tuhaha.

Dolmen-dolmen peninggalan di Negeri Tuhaha merupakan struktur pandangan dan cara hidup masyarakat pada waktu itu, sekarang dan bahkan pada masa-masa mendatang. Seubstansi hidup pada masamasa tersebut, tidak dapat dipungkiri akan masa transisi dan perubahan-perubahan yang terjadi, baik pada segi interkasi, integras maupun struktur sistem. Matarumah/fam/ marga pada gambar diatas secara ekplisit juga terintegral dalam dolmen-dolmen tersebut, misalnya :

1. Dolmen Sahusilawane; matarumah/fam/ marga sahusilawane struktur hubungan dengan dolmen sahusilawane, dan dikelompokkan dalam soa samasulu dan silouw

2. Dolmen supusepa: ; matarumah/fam/ marga supusepa struktur hubungan dengan dolmen supusepa, dan dikelompc dalam soa lounusa

3. Dolmen pattipeiluhu; matarumah/fam/ marga pattipeiluhu struktur hubungan dengan dolmenpattipeiluhu, dan dikelompokkan dalam soa kelluhu.

4. Dolmen aipassa; matarumah/fam/marga aipassa struktur hubungan dengan dolmen aipassa, dan dikelompokkan dalam soa samasulu.

5. Dolmen siwalima: dolmen besar yang digunakan sebagai struktur integrasi keseluruhan dolmen (dolmen sahusilawane, aipassa, supusepa, pattipeiluhu). logi dolmen siwalima adalah struktur dasar sistem
pengelompokan masyarakat pada waktu itu.

Tabel 1. Matarumah/fam/marga yang ada di Negeri Tuhaha menurut pengelompokan soa.

\begin{tabular}{|c|c|c|c|}
\hline No & $\begin{array}{l}\text { Nama } \\
\text { Soa }\end{array}$ & Matarumah/fam/marga & Keterangan \\
\hline 1 & Pololouw & $\begin{array}{l}\text { Tanalepy, louhenapessy, } \\
\text { matelhemual }\end{array}$ & - \\
\hline 2 & Kelluhu & $\begin{array}{l}\text { Pattipeiluhu,pollatu, } \\
\text { latthenawakan, tehumana, } \\
\text { peilokonon, telupatawala, } \\
\text { nustan }\end{array}$ & - \\
\hline 3 & Samasulu & $\begin{array}{l}\text { Makelupessy, } \\
\text { sahusilawane, lopulisa, } \\
\text { aipasa, sahenaya, } \\
\text { tolmolya, pattileka, sapia. }\end{array}$ & - \\
\hline 4 & Matita & $\begin{array}{l}\text { Loupatty, makilepessy, } \\
\text { tatipikalawan, sasabone, } \\
\text { siwalette, pakalesia. }\end{array}$ & - \\
\hline 5 & Lounusa & $\begin{array}{l}\text { Supusepa, hallatu, } \\
\text { lopulisa, matakena, } \\
\text { nanuwasa. }\end{array}$ & - \\
\hline 6 & Louhena & $\begin{array}{l}\text { Malakousaiaya, } \\
\text { polhaupessy, taribuka, } \\
\text { pattilekasapia, } \\
\text { louhenapessy, pollatu. }\end{array}$ & - \\
\hline 7 & Silouw & $\begin{array}{l}\text { Sahusilawane, siwalete, } \\
\text { polhaupessy, tehusiarana, } \\
\text { paliama. }\end{array}$ & - \\
\hline 8 & Amutai & - & Hilang \\
\hline 9 & Sopake & - & Hilang \\
\hline
\end{tabular}

(Sumber: Data Hasil Penelitian)
Dalam pandangan interaksi simbolik, sebagaimana ditegaskan Blumer (Mulyana, 2010 : 70) proses sosial dalam kehidupan kelompoklah yang menciptakan dan menegakkan aturan-aturan, bukan aturanaturan yang menciptakan dan menegakkan kehidupan kelompok. Hubungan dolmen, menhir negeri lama, permukiman lama dengan masyarakat adalah suatu prose sosial di dalam sistem yang berjalan menjaga keseimbangan antara satu bagian dengan bagian yang lain.

\section{PENUTUP}

Pola pengelompokan masyarakat Negeri/Desa Tuhaha mengalami dinamika sosial budaya sesuai implikasi dari perkembangan zaman. Satu hal yang paling mendasar adalah tinggalan arkeologi (dolmen, menhir, permukiman lama/negeri lama) merupakan pemahaman dan pandangan tersendiri bagi struktur masyarakat Tuhaha. Implikasi tersebut dapat dilihat dalam susunan dan bentuk pengelompokan masyarakat atas dasar tinggalan arkeologis.

Pemaknaan konteks dolmen, menhir huhule dipandang sebagai satu kesatuan sistem struktur utuh berproses dari dulu, sekarang bahkan masa akan datang. Hal ini juga membuat konstruksi sosial budaya masyarakat setempat menjadi lebih bermakna, dan besifat mengikat. Kronologis penggelompokkan berdasarkan tinggalan arkeologis menjelaskan bahwa ada prosesproses dinamika sosial budaya didalamnya dari huhule berkumpul 9 (sembilan soa) dengan 5 (lima) dolmen batu meja, sebaga sarana konstruksi budaya pada waktu itu.

\section{DAFTAR PUSTAKA}

Binford, Lewis R. 1972. An Archaeological Perspective. New York
London Seminar Press.

Clarke, David L. 1977. "Spatial Information in Archaeology". Dalam Spatial 
Dilistone, F. W. 2002. The Power Of Symbols. Jogjakarta: Kanisius.

Geria, I Made. 2008. Kearifan Lokal dalam Pengelolaan Lingkungan di Bali (Kajian dari data Arkeologi). Jakarta: Ikatan Ahli Arkeologi Indonesia (IAAI). Hal 89-94.

Hodder, Ian. 1986. Reading in the Past: Current Approach in Interpretation in Archaeology. Sydney: Cambridge University Press.

Huliselan, Mus. 2005. Berdampingan Dalam Perbedaan Konsep hidup Anak Negeri. Maluku Menyambut Masa Depan. Ambon: Maluku. Lembaga Kebudayaan Daerah Maluku. Hal 222-243.

Mulyana, Deddy. 2010. Metodologi Penelitian Kualitatif. Bandung: PT. Remaja Rosdakarya.

Sahulteru, Salhuteru. 2008. Pola Sebaran dan Penempatan Dolmen Di Kecamatan Saparua Maluku Tengah. Berita Penelitian Arkeologi Ambon Vol. 4 No. 6 Juli. Ambon: Balai Arkeologi Ambon. Hal 76-102.

Soerjono, Soekanto. 1990. Sosiologi Suatu Pengantar. Jakarta: CV. Rajawali.

Sihasale, Wem R. 2005. Pola Pengelompokan Masyarakat Adat dan Sistem Pemerintahan Adat Di Maluku. Maluku Menyambut Masa Depan. Ambon: Lembaga Kebudayaan Daerah Maluku. Hal 67-88.

Tanudirjo, Daud. 2009. Memikirkan Kembali Etnoarkeologi. Jurnal Penelitian Arkeologi Papua dan Papua Barat. Jayapura: Balai Arkeologi Papua. Hal 1-15. Vol. 1 No. 2 / November.

Tim Penyusun. 2008. Metode Penelitian Arkeologi. Cetakan kedua. Jakarta: Pusat Penelitian dan Pengembangan Arkeologi NasionalBadan Pengembangan Sumberdaya Budaya dan Pariwisata. Kementerian Kebudayaan dan Pariwisata. 